\title{
Changes in the organic carbon resources in successive forest development stageson dunes in the Torun Basin
}

\author{
Milosz Deptuła, Anna Kruczyńska \\ Nicolaus Copernicus University, Faculty of Biology and Environmental Protection, Chair of Geobotany and Land- \\ scape Planning, Lwowska 1, 87-100 Toruń, Poland \\ e-mail: deptula@umk.pl
}

\begin{abstract}
One way to prevent the growing carbon dioxide amount in the atmosphere consists in afforestation of forest wastelands such as: heaths, peat bogs, swamps. Replacing such ecological systems by planting them with trees allows to increase the afforested area and, at the same time, to increase the accumulation of organic carbon in the plant biomass. The growing contribution of forest stands may lead to natural restoration, mostly by self-seeding.

This study determined changes in the organic carbon resources at the following stages of the natural succession occurring on heaths. The changes were compared with values obtained for the pine cultivation developed from artificial afforestation of the inland dune. The study was conducted on the heathland near the southern boundary of Torun. Four plots were established in the gradient of the increasing density of pine. The second object of the study was an artificial pine cultivation established on the suburban inland dune (Zadroże Dune). The heather was preserved in abundant quantities in places where wilding pine trees occurred in small numbers (plot I), whereas in places with older self-sown plants (plots III and IV), the heath covered only a small part of the study area, beneath the canopy gaps allowing greater sunlight penetration. The artificial forest cultivation established on a dry habitat with trees three times older compared to self-sown pines on the heathland accumulates similar amounts of carbon in the biomass. The performed analysis showed that there are no significant differences in the carbon resources accumulated in the artificial and well-developed forest eco-

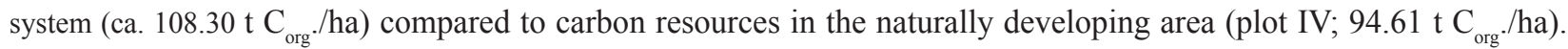

Key words: afforestation, Calluna vulgaris, forest cultivation, heath, inland dunes, Torun.

\section{Introduction}

Global climate changes and the accompanied transformations within the biosphere induced by an increase in the $\mathrm{CO}_{2}$ concentration in the Earth's atmosphere are one of the most important problems of the contemporary ecology (Breymeyer, 1998; Breymeyer et al., 1998). Carbon dioxide $\left(\mathrm{CO}_{2}\right)$ is the main greenhouse gas. Since the beginning of intensive measurements of its concentration in the atmosphere (i.e. 1958), the amount of this gas has been gradually increasing (Keeling et al., 1989; Bernadzki, 2011). The atmospheric carbon fixation by forest ecosystems and their impact on the global carbon balance are discussed for almost all countries with a high afforestation rate, both on a local, regional, national and continental scale (Bhatti et al., 2002; Birdsey \& Lewis, 2003; Cannell, 2003; Finèr et al., 2003; Karjalainen et al., 2002, 2003; Kurbanov \& Post, 2002; Liski et al., 2002; Mund et al., 2002; Nabuurs \& Schelhaas, 2003; Orihuela-Belmonte et al., 2013; Patenaude et al., 2003; Vucetich et al., 2000; Zhang \& Xu, 2003; Zhang et al., 2012; Zhong et al., 2003).

When analysing the possible solutions to mitigate the growing "greenhouse effect", it has been frequently emphasized that the increasing content of $\mathrm{CO}_{2}$ in the atmosphere should be inhibited by increasing the retention of carbon in the biosphere and lithosphere.

The accumulation of carbon in plant biomass may prevent this effect. In particular, forest ecosystems accumulate 
large amounts of carbon in living and dead organic matter (Burschel et al., 1993). The worldwide research indicates that mostly tropical forest accumulates large amounts of carbon and plays a significance role in the carbon cycle (Orihuela-Belmonte et al., 2013). Furthermore, it has been proved that plantations of acacia and eucalyptus in the climate of China are good resources of biomass, and consequently very well accumulate organic carbon and reduce its content in the atmosphere (Zhang et al., 2012).

One way to prevent the growing amount of carbon dioxide in the atmosphere is through afforestation of forest wastelands, e.g. heaths, peat bogs, swamps. Replacement of such ecological systems by cultivation of trees (usually pine) contributes to an increased accumulation of organic carbon in plant biomass. On the other hand, such ecosystems being ecological sites are, at the same time, refugia of biodiversity. They often determine the tourist attractiveness of a given area and stimulate the economic development (beekeeping, sometimes livestock grazing). A variety of functions performed by ecological sites are the cause of disputes between foresters, ecologists and scientists, because on the one hand, the afforestation of these sites is advantageous since it is followed by an increase in the accumulation of carbon through an increase in the afforested area, while on the other hand, it involves extinction of this kind of ecosystems.

In the nature conditions of Central Europe, heaths are a common type of ecosystems, naturally or artificially afforested. Their preservation is very important for the nature conservation and requires a lot of research, including in particular a precise description of the sites. The major problem is, however, classification of heaths as wastelands which should be afforested (Dyrektor Generalny Lasów Państwowych, 2003, 2012). These processes were described by Oheimb et al. (2008) and Lauschner and Rode (1999), and they have contributed to the disappearance of common heather in many areas. Due to extensive afforestation conducted in Poland in recent years, the contribution of heaths in the land use structure and the land cover has significantly declined (GIOŚ, 2012). The development of forest as a consequence of heathland afforestation was studied by e.g. Nienartowicz et al. $(2002,2009)$ well Rode (1999a, b).

Afforestation can be carried out not only through artificial forest restoration, but also through natural processes, mainly self-seeding. Consequently most of the heath on the Zadroże Dune near the city of Torun disappeared after the early 1960s (Nienartowicz et al., 2009) and Calluna vulgaris (L.) was replaced, in a natural way, by young wilding trees after the land-use change.

For a better understanding and advancement of knowledge about the European heathlands, the European Heathland Network was designated. Owing to such networks, it is possible to formulate the economic policy in relation to heaths, which would allow their special protection as a unique and vanishing ecological systems.

The aim of the present paper was to determine changes in the organic carbon resources in subsequent phases of natural vegetation encroachment on dune heaths in the Torun Basin. These changes were compared with values obtained for a pine plantation developed from artificial afforestation of the inland dune. In addition, it has been assumed that phytocoenoses of artificial pine plantations are significantly different from natural phytocoenoses developed from self-seeding pine in respect of the total resources of plant biomass and organic carbon accumulated in the biomass.

\section{Study area}

The research was carried out near the southern border of Torun, in the district of Podgórz, in the vicinity of the village Mała Nieszawka (Fig. 1). The selected study area is situated between the S10 express road, the former Torun - Inowrocław road and the railway line to Inowrocław and Poznań (Miejska Pracownia Urbanistyczna w Toruniu, 2006). Four experimental plots were located in this area.

The study area is a dune with sandy soils covered with many heaths. The woods of Scots pine Pinus sylvestris occurring on the heathland come mostly from self-seeding. This is evidenced by a characteristic habit of pine trees and their low height as compared to DBH (diameter at breast height). Such a habit formation of pine in the forest stand derived from self-sown plants was described by e.g. Białobok et al. (1970). Pine trees growing on the studied dune are branching from the soil surface, which means that the maintenance treatments were not implemented in the forest stands. Some pine specimens grow very close to each other, which further confirms that the analysed community is not a forest plantation. In places where more light penetrates through the open canopy of trees, the abundant development of the common heather was observed. Dwarf shrubs completely disappeared on the Zadroże Dune, which was artificially afforested (Nienartowicz et al., 2009). The dune is located at a distance of ca. $1 \mathrm{~km}$ north-west of the studied heath and covers an area of ca. 5.48 ha (Fig. 1).

It appears from the research by Okołowicz (1949) that primeval forest growing on the Zadroże Dune was cut down ca. 1870. This is confirmed by Ankniejówna and Górska (1949) who argue that before 1949 the dune was covered with forest as evidenced by trunks of old trees which still remain in the area. Planned forestry began only in the mid-19th century, so it can be assumed that forest growing on the dune in the 19th century was of natural origin. Also between 1870 and 1949, trees spontaneously occurred on the dune area. However, the process of natural 

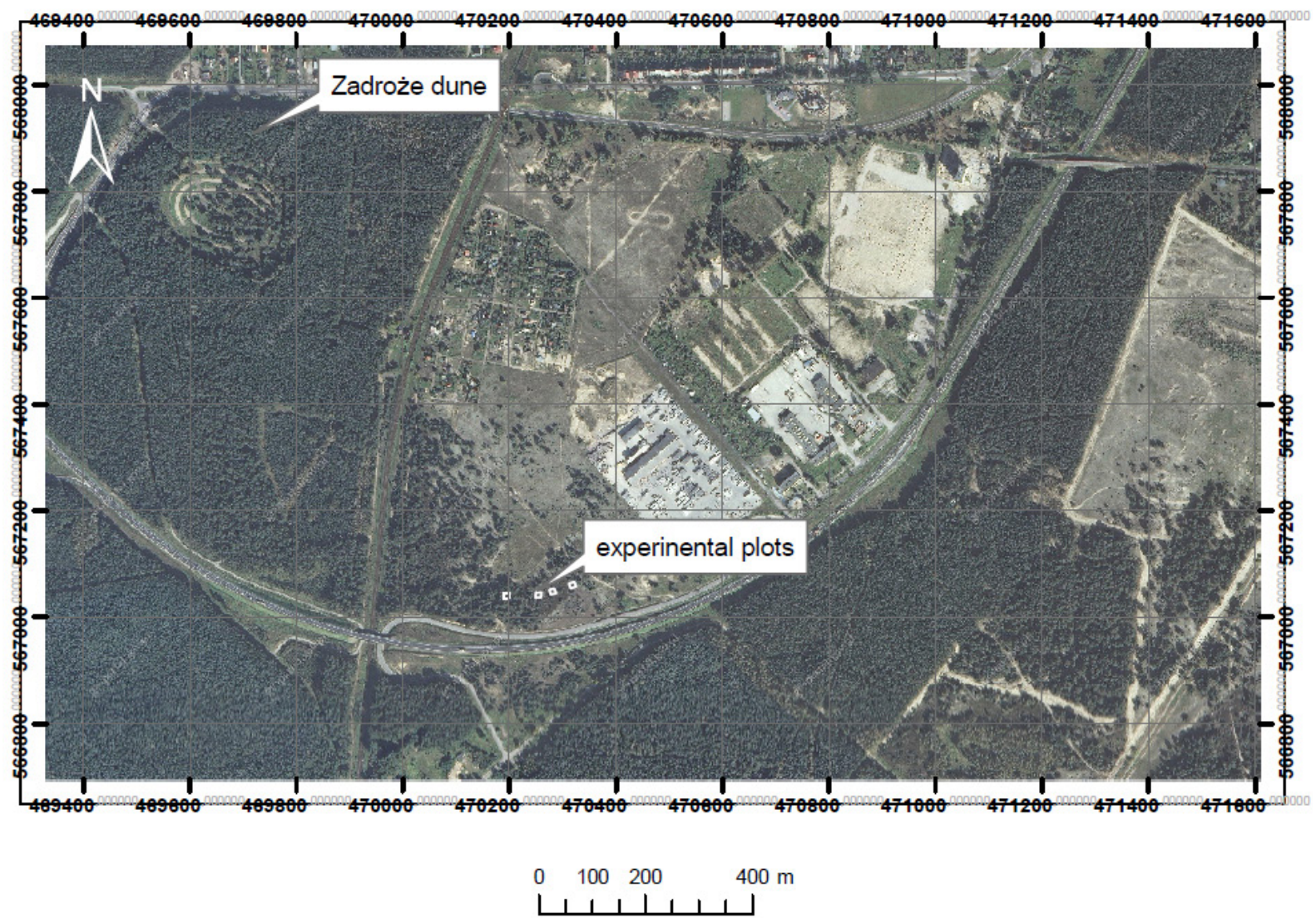

Figure 1. Location of the study area

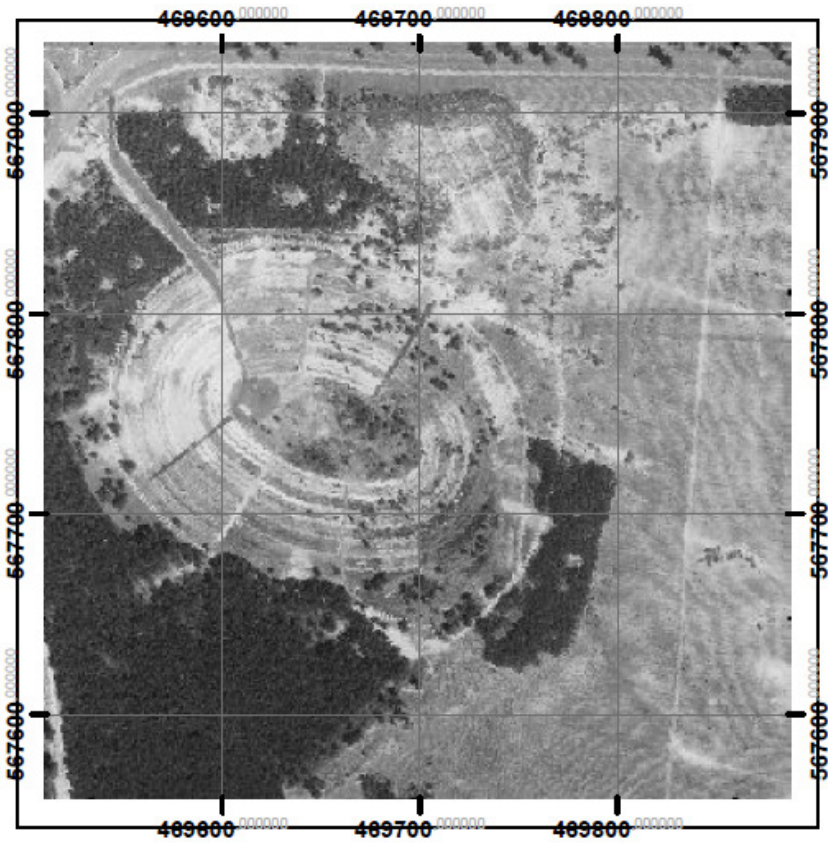

$0 \quad 37,575$

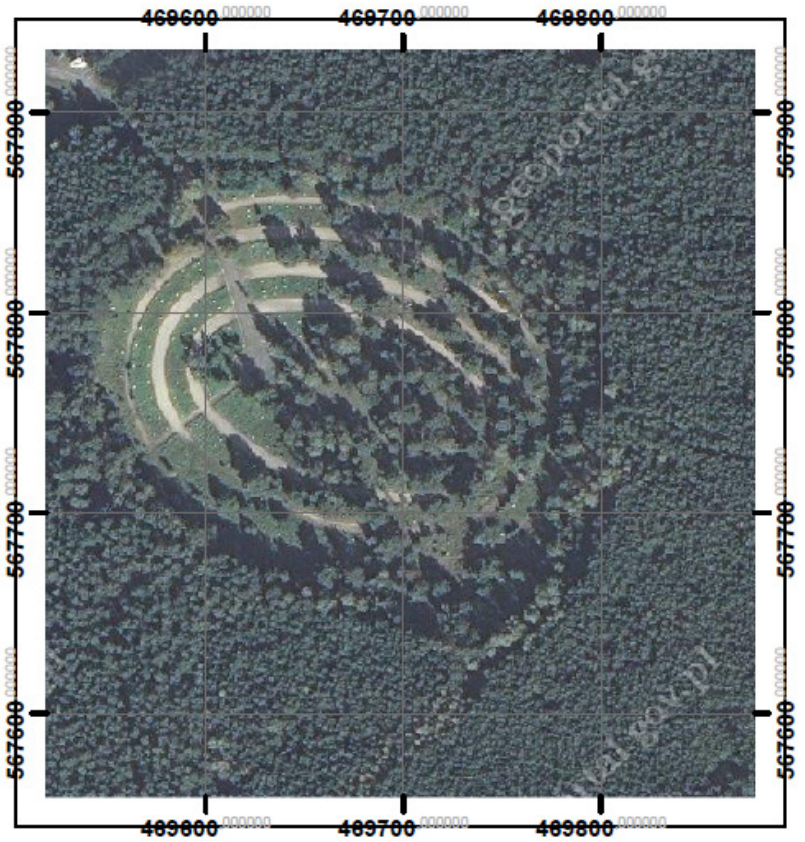

$150 \mathrm{~m}$

Figure 2. Land use of the Zadroże Dune area in 1961(A) and 2004 (B) 
forest development on the dune was very slow. Artificial forest reconstruction on the dune proceeded in several stages. It started in 1950 with afforestation of the central part of the dune; the second fragment was afforested in 1959. The eastern part of the dune was afforested in two stages, i.e. in 1966 and 1983 (Fig. 2). According to Kruczyńska (2012), the total area of the present-day forest growing on the Zadroże Dune is 3.71 ha. The dune afforestation process was presented by Nienartowicz et al. (2009) on a series of topographic maps.

\section{Methods}

Four experimental plots were selected on the heathland (Fig. 3), each with an area of $100 \mathrm{~m}^{2}(10 \mathrm{~m} \times 10 \mathrm{~m})$. The plots were located in the transect of the increasing pine density, from the site with the smallest density (I) to the site with a dense canopy of trees (IV). The sites were located within a short distance from each other and represented different stages of the forest developing as a result of natural regeneration.

At each site, dendrometric measurements were taken and the age of trees was determined. The diameter at breast height was measured using a DBH meter (at a height of $1.3 \mathrm{~m}$ from the ground), and their height was determined using a height meter SUUNTO PM5/1520. If one tree branched out into two or three thick boughs, the DBH and the height of each bough were measured. The age of self-seeding trees was determined by a classic method consisting in counting the whorls and adding two years to the result obtained, as recommended by Łukaszkiewicz (2011). On this basis, the plant biomass at each study site was assessed. The trunk volume of each tree was assessed according to yield tables of trees (Czuraj, 1990). If the determination of these values was not possible directly from the tables, interpolated values were used. If the tree branched out into two or three thick branches, the biomass of all branches was added up. When assessing the biomass, the specific gravity was adopted for the 80-year-old forest stand, i.e. $0.49 \mathrm{t} / \mathrm{m}^{3}$ (Krzysik, 1978). The biomass of tree trunks was calculated based on the calculation of average reserves in $\mathrm{m}^{3} / \mathrm{ha}$. Next, the biomass of the canopy was calculated using the value of the T/M index equal to 1.33 (Deptuła, 2006), according to Murillo-Rodriquez's methodology $(1994,1997)$. When estimating the biomass of the underground parts of trees, it was assumed that roots accounted for $14 \%$ of the whole tree's biomass (Laurow

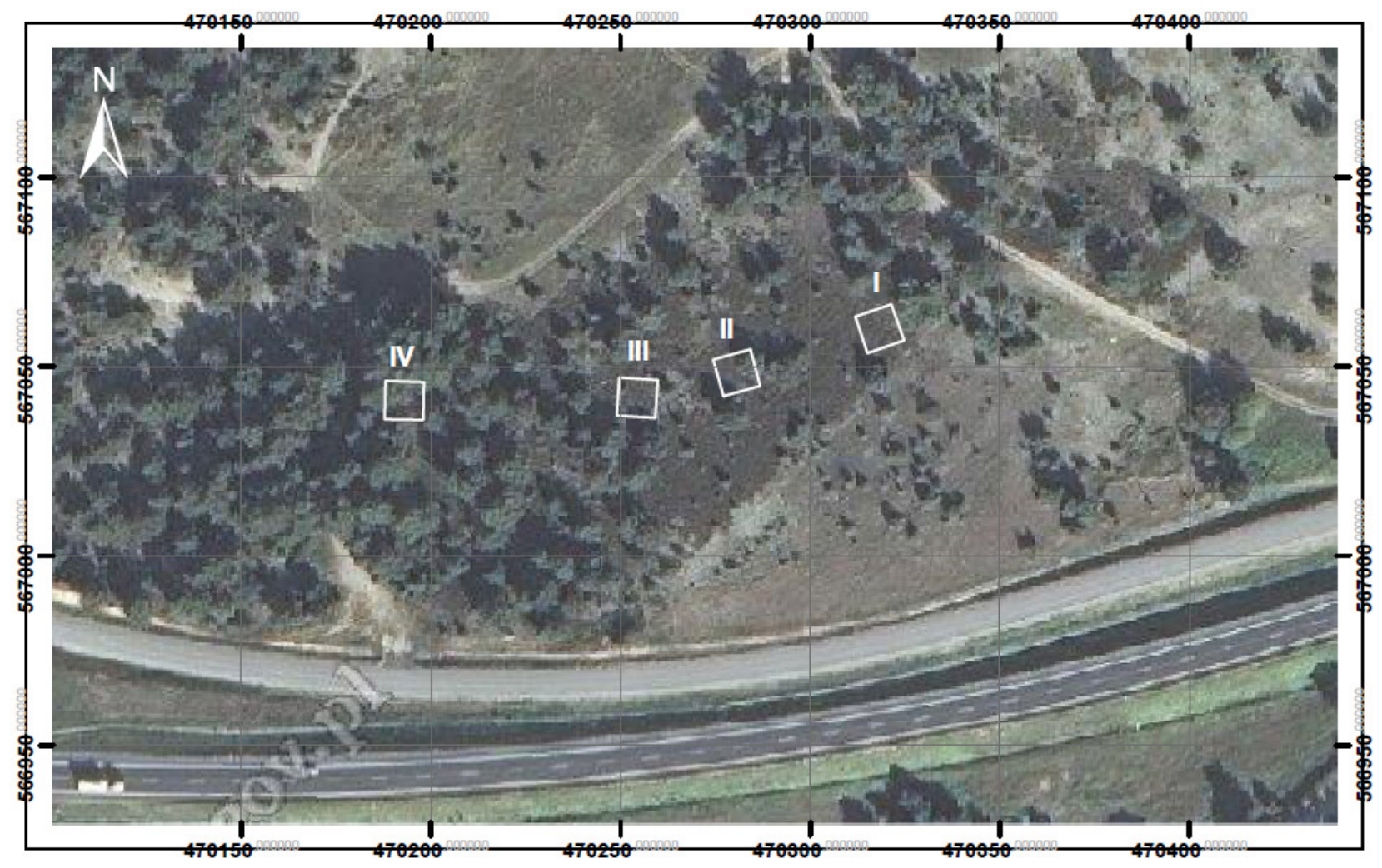

\begin{tabular}{llll}
0 & 12,5 & 25 & 50 \\
\hline
\end{tabular}

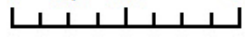

Figure 3. Location of the experimental plots (I-IV) 

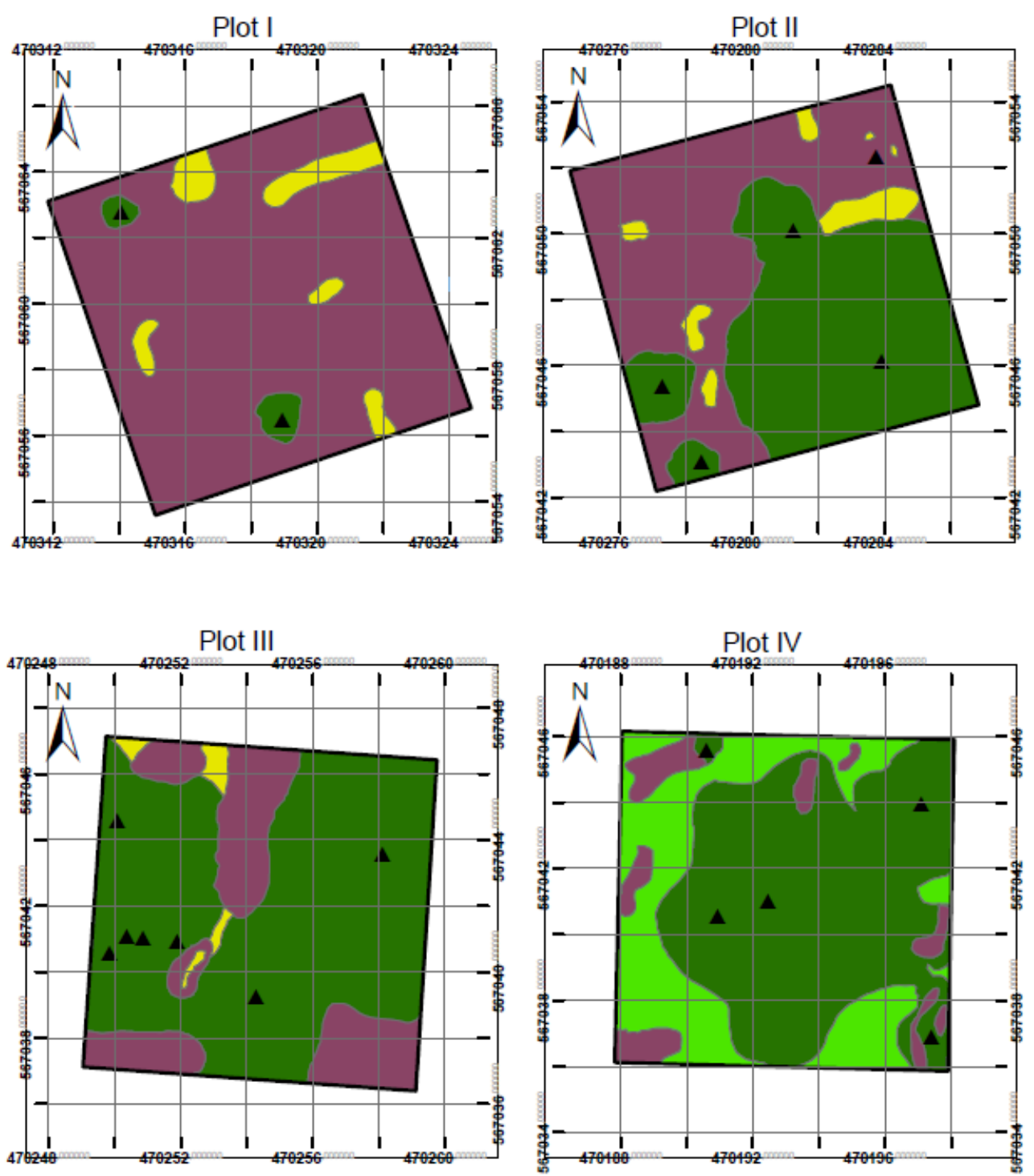

\section{Legend}

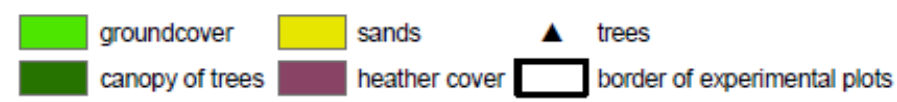

$\begin{array}{llll}0 & 1,25 & 2,5 & 5 \mathrm{~m}\end{array}$

Figure 4. Cover of the experimental plots

1966; Fonseca, et al. 2011). The amount of biomass contained in the undergrowth was calculated according to the value of the index quoted for dry coniferous forest, i.e. $1.94 \mathrm{t}$ d.m./ha (Deptuła 2004). Whereas for non-forest ecosystems such as heath, the index was $6.66 \mathrm{t} \mathrm{d} . \mathrm{m} . / \mathrm{ha}$ (Lieth, 1975; Whittaker, 1975; Whittaker \& Marks, 1975; Traczyk, 1968, 1971).

Furthermore, the content of organic carbon was calculated on the basis of the estimated biomass at each experimental plot of the analysed forest, both in the plant biomass of the tree layer and in the remaining vegetation components of the ecosystem. It was assumed that organic carbon accounts for $50 \%$ of the dry plant biomass (Deptuła, 2004).

To compare the sites overgrown with self-seeding pine and artificial plantings of pine, the results of the previous research conducted on the Zadroże Dune as part of a BSc thesis were used (Kruczyńska, 2012).

The distribution of trees and the vertical projection of their crowns were determined at the experimental sites in 
the grid of squares $1 \mathrm{~m} \times 1 \mathrm{~m}$ (Fig. 4). In addition, the sites overgrown with common heather Calluna vulgaris (L.) were marked.

The location of the study sites was presented using the ArcGIS 9.3.1 software and the aerial photographs available on the website (www.geoportal.gov.pl). Furthermore, a database for each study plot was compiled. The databases were used to create distribution maps of heather and individual trees with the vertical projection of their crowns, and the area covered by the former and the latter was calculated.

\section{Results}

Figure 4 presents the vegetation cover of each study site. Only two young pine specimens with an average DBH of $2.12 \mathrm{~cm}$ and a height of $0.3 \mathrm{~m}$ and $2 \mathrm{~m}$ occurred in plot I. The average age of these trees was assessed at 6 years. Most of the plot was overgrown with common heather $\mathrm{Cal}$ luna vulgaris (L.); the remaining part of plot I was covered with vegetation characteristic of dry grasslands with such species as e.g.: Dicranum undulatum (Schrad.) and Pleurozium schreberi (Willd.).

Five specimens of Scots pine grew at site II. One of the trees was branchy and divided into four boughs; the vertical projection of its crown covers a considerable part of the plot. The four other trees were young and hence not so large. The common heather Calluna vulgaris (L.); developed under the smallest pine. Empty spaces outside the vertical projections of the crowns are covered mainly with grasses of dry habitats with some admixture of mosses and epigeic lichens from the genera Cladonia. The average $\mathrm{DBH}$ of the pine trees occurring at this site is $11.7 \mathrm{~cm}$, the average height $-6.17 \mathrm{~m}$ and the mean age was estimated at 16 years.

At plot III, seven specimens of Scots pine were inventoried. One of the trees was branchy and divided into four trunks. Three other pine specimens growing on plot III had DBH of 15-26 cm and one pine was divided into two boughs: one thinner $(7.5 \mathrm{~cm})$ and one thicker $(17 \mathrm{~cm})$. One specimen of Pinus sylvestris (L.) was a young tree with $\mathrm{DBH}$ of $4 \mathrm{~cm}$. The average age of trees was estimated at 22 years. The vertical projection of the tree crowns covers a considerable part of the plot, while the heather occupies a small area. Calluna vulgaris (L.) developed mainly along the plot's peripheries, i.e. in places where the canopy of trees was less dense and the light could penetrate through the branches of the trees. The study sites not covered by the vertical projection of the tree crowns or by the heather were covered with plants characteristic of dry grasslands, e.g. Dicranum undulatum (Schrad.) and lichens from the genus Cladonia.

Of all four plots, plot IV with five specimens of Scots pine most closely resembles the developed forest ecosys- tem. The age of pine trees was determined as 28 years, i.e. the oldest of the inventoried trees. Two trees were branchy and divided into three trunks. In addition to these

pine trees, two specimens with $\mathrm{DBH}$ of $10 \mathrm{~cm}$ and $16 \mathrm{~cm}$ occurred at plot IV. The fifth pine was a young tree with DBH of $4 \mathrm{~cm}$. The vertical projection of the tree crowns covered ca. 2/3 of the plot. Heather specimens occurred in the form of a few small clusters (Table 1). The remaining part of the plot was much shaded and covered with undergrowth characteristic of dry coniferous forest, including mainly Dicranum undulatum (Schrad.) and Pleurozium schreberi (Willd.).

Table 1. Description of the study sites (I-IV)

\begin{tabular}{|c|c|c|c|c|}
\hline $\begin{array}{c}\text { experimental } \\
\text { plot }\end{array}$ & $\begin{array}{c}\text { heather } \\
\text { cover } \\
{\left[\mathrm{m}^{2}\right]}\end{array}$ & $\begin{array}{c}\text { canopy of } \\
\text { trees } \\
{\left[\mathrm{m}^{2}\right]}\end{array}$ & $\begin{array}{c}\text { groundcover } \\
{\left[\mathrm{m}^{2}\right]}\end{array}$ & $\begin{array}{c}\text { sands } \\
{\left[\mathrm{m}^{2}\right]}\end{array}$ \\
\hline I & 91.96 & 2.01 & - & 6.03 \\
\hline II & 45.67 & 50.91 & - & 3.42 \\
\hline III & 19.77 & 78.29 & - & 1.94 \\
\hline IV & 7.49 & 62.96 & 29.55 & - \\
\hline
\end{tabular}

It appears from the data contained in Table 1 that plot I was dominated by heather, while the crowns of trees covered only a small area. Plot II was covered in $50 \%$ by the heather and the other $50 \%$ of the plot was shaded by the crowns of trees. As much as $80 \%$ of plot III was covered by the canopy of trees, while the common heather covered over $20 \%$. The value of over $100 \mathrm{~m}^{2}$ at this plot results from the overlapping areas covered by the projection of tree crowns and heather. Over $60 \%$ of site IV was under the crown of trees, $8 \%$ was covered with heather, and the remaining ground surface was covered with undergrowth vegetation typical of dry coniferous forest.

Table 2 presents the comparison of all plots. With the increasing code number of the plots, and hence the increasing density of the trees, the content of biomass and the content of organic carbon in the plant material were increasing too. On the other hand, the amount of biomass associated with the common heather was decreasing. The undergrowth covered a small area at each plot and it was assumed that the value of this parameter at site III was zero.

Table 3 presents the comparison of the biomass and the organic carbon content on the Zadroże Dune in 1949, i.e. at the time when the area was mostly covered with heath and in 2009 (after afforestation), i.e. when the area was overgrown with Scots pine in nearly $100 \%$. It appears from the data that trees accumulated over 10 times more organic carbon compared to the heathland and non-forest communities. 
Table 2. The content of biomass and organic carbon at each plot, taking into account different components of the ecosystem (trees, undergrowth, heath)

\begin{tabular}{|c|c|c|c|c|}
\hline & $\begin{array}{l}\text { experimental plots } \\
\text { I }\end{array}$ & $\begin{array}{l}\text { experimental plots } \\
\text { II }\end{array}$ & $\begin{array}{l}\text { experimental plots } \\
\text { III }\end{array}$ & $\begin{array}{l}\text { experimental plots } \\
\text { IV }\end{array}$ \\
\hline $\begin{array}{l}\text { The amount of biomass in the forest stand } \\
{[\text { t d.m. }]}\end{array}$ & 0.0013 & 0.4981 & 0.7963 & 1.8813 \\
\hline $\begin{array}{l}\text { The amount of biomass in the groundcover } \\
\text { [t d.m.] }\end{array}$ & 0.0009 & 0.0002 & 0.000 & 0.0055 \\
\hline $\begin{array}{l}\text { The amount of biomass in the heath } \\
\text { [t d.m.] }\end{array}$ & 0.0616 & 0.0312 & 0.0153 & 0.0054 \\
\hline TOTAL: & 0.0639 & 0.5295 & 0.8116 & 1.8922 \\
\hline $\begin{array}{l}\text { Corg. content } \\
{\left[\mathrm{t} \mathrm{C}_{\text {org }} \cdot\right]}\end{array}$ & 0.0320 & 0.2648 & 0.4058 & 0.9461 \\
\hline $\begin{array}{l}\text { Corg. content } \\
{\left[\mathrm{t} \mathrm{C}_{\text {org }} \cdot / \text { ha }\right]}\end{array}$ & 3.20 & 26.48 & 40.58 & 94.61 \\
\hline
\end{tabular}

Table 3. The land-use structure and the amount of plant biomass in different land-use forms on the Zadroże Dune in 1949 and 2009 (Kruczyńska, 2012)

\begin{tabular}{|c|c|c|c|c|}
\hline \multirow{2}{*}{$\begin{array}{c}\text { Land use structure } \\
\text { Year }\end{array}$} & \multicolumn{2}{|c|}{$\begin{array}{l}\text { Area } \\
{[\text { ha }]}\end{array}$} & \multicolumn{2}{|c|}{$\begin{array}{l}\text { Total biomass } \\
{[\mathrm{t} \text { d.m. }]}\end{array}$} \\
\hline & 1949 & 2009 & 1949 & 2009 \\
\hline Forest stand & 0.05 & 3.71 & 13.81 & 1024.84 \\
\hline Heathland & 0.59 & 0.03 & 6.45 & 0.33 \\
\hline Cemetery & 0.28 & 0.29 & 7.36 & 7.62 \\
\hline $\begin{array}{l}\text { Grasslands (roadside and } \\
\text { xerothermic grasslands) }\end{array}$ & 2.54 & 0.84 & 80.66 & 22.07 \\
\hline $\begin{array}{l}\text { Others (sands, roads, } \\
\text { monument, ruins of } \\
\text { buildings) }\end{array}$ & 2.02 & 0.61 & - & - \\
\hline TOTAL: & 5.48 & 5.48 & 108.28 & 1054.86 \\
\hline \multicolumn{3}{|c|}{$\begin{array}{l}\text { The content of carbon in plant biomass } \\
{\left[\mathrm{t} \mathrm{C}_{\text {org. }}\right]}\end{array}$} & 54.14 & 527.43 \\
\hline \multicolumn{3}{|c|}{$\begin{array}{l}\text { The content of carbon in plant biomass } \\
\text { per } 1 \text { ha }\left[\mathrm{t}_{\text {org. }} / \text { ha }\right]\end{array}$} & 15.65 & 108.30 \\
\hline
\end{tabular}

\section{Discussion and conclusions}

For many years, the extensive scientific studies and discussions have been conducted worldwide to understand the origin of the greenhouse effect and to develop the best reduction methods. The problem of $\mathrm{CO}_{2}$ concentration in the atmosphere is often discussed by different researchers, both in Poland (Breymeyer, 1998; Breymeyer et al., 1998) and abroad (Hansen, 2009). After years of publicizing the problem and modernization of the industry towards the reduction of $\mathrm{CO}_{2}, \mathrm{NO}_{x}$ and $\mathrm{SO}_{\mathrm{x}}$ emissions, scientists began to develop methods which will further reduce the amount of carbon dioxide in the atmosphere (IPCC, 2007). In the USA in 1995, large industrial enterprises have invested more than 2.5 million USD to create an organization that would deal with reduction of the carbon dioxide content in the atmosphere. The main objective of this organization was to create eight projects which would combine the implementation of measures aimed at reduction of the $\mathrm{CO}_{2}$ amount (e.g. planting of trees in rural areas, forest conservation) with funding the research related to this problem (Kinman et al., 2000). This initiated the process of afforestation of forest wastelands such as heaths.

In Poland, heaths are associated mainly with active or abandoned military training grounds (GIOŚ, 2012). The forest administration considers the abandoned military training grounds as wastelands. After the process of land reclamation, which often involves mine clearance, forest plantations are established and consequently the heath ecosystems disappear.

Natural regeneration of forest is yet another factor that causes withdrawal of the common heather. Large and exposed areas of heaths on former military training grounds are relatively quickly colonized by self-sown trees, mainly pine, and consequently the heath ecosystems disappear. This effect was observed on the experimental plots. The heather was preserved in abundant quantities in places where wilding pine trees occurred in small numbers (plot I), whereas in places with older self-sown plants (plots III and IV), the heath covered only a small part which allowed 
greater sunlight penetration. As evidenced by the studies of e.g. Nienartowicz et al. (2002) and Amici et al. (2012), the afforestation reduces the species diversity because of the forest species dominance. of the study area beneath the canopy gaps,

The artificial forest plantation established on a dry habitat with trees three times older compared to self-sown pines growing on the heathland with characteristic trees of small height and relatively large DBH accumulates similar amounts of carbon in the biomass. The performed analyses showed that there are no significant differences in the carbon resources accumulated in the artificial, well-developed forest ecosystem from 2009 (ca. 108.30 t C $_{\text {org }}$. $/$ ha) compared to the carbon resources in the naturally developing

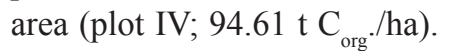

A similar relationship was observed in the studies carried out in Australia, which proved that there was no difference in the amount of accumulated carbon between the forest plantation and the natural forest (Preece et al., 2012).

Based on the amount of carbon accumulated in the plant biomass, the physiognomy of the plant community growing on the Zadroże Dune in 1949 could be described as a transitional stage between the state observed at plot I of the studied heath $\left(3.20 \mathrm{C}_{\text {org }}\right.$ ha $)$ and the succession stage observed at plot II (26.48 $\mathrm{C}_{\text {org./. }}$ ha).

In the context of greenhouse-effect prevention through $\mathrm{CO}_{2}$ absorption from the atmosphere, it is not important whether the habitats with a very low trophic status are planted with trees or left to natural succession. Natural forest regeneration is, however, less invasive compared to forest plantations as it allows the coexistence of a forest and a heath, or a peat-bog, for a long time. This co-occurrence takes place at least in the initial phase of the development. Later, as evidenced by scientific studies, uncontrolled and robust self-sown plants cause disappearance of heaths and other non-forest communities.

It is also worthwhile to consider the possibility of reconstruction of some heaths through timber harvesting from forest stands of natural origin. Monitored and wellplanned treatments would increase the penetration of light down to the forest floor, and consequently the growth of heather. The timber obtained from trees growing in natural ecosystems does not have economic importance (except for fuel) because of several defects. Nevertheless, for the same reason (bends, knots) it may represent an interesting raw material used by the local craftsmen, e.g. to make furniture or floor boards with an interesting pattern.

\section{References}

Anikiejówna Cz. \& Gorska J., 1949, Stosunki florystyczne i fitosocjologiczne wydmy Zadroże [Floristic and phytosociological relationships of the Zadroże Dune], [in:]
J. Prüffer (ed.), Z badań zespołowych wydmy Zadroże [Collective investigations on the Zadroże Dune near the city of Toruń], Studia Societatis Scentiarum Torunensis, Supplementum, I: 27-36.

Amici V., Rocchini D., Geri F., Bacaro G., Marcantonio M. \& Chiarucci A., 2012, Effects on an afforestation process on plant species richness: A retrogressive analysis, Ecological Complexity, 9: 55-62.

Bernadzki E., 1995, Gospodarka leśna w obliczu zmian klimatu [Forest management in the face of climate change], Sylwan 1995/1: 19-32.

Bhatti J.S., Apps M.J. \& Jiang H., 2002, Influence of nuturients, disturbances and site conditions on carbon stocks along a boreal forest transect in central Canada, Plant and Soil, 242: 1-14.

Białobok S., Błaszyk H., Giertych M., Hejnowicz A., Obmiński Z., Przybylski T., Siwecki R., Staszkiewicz J. \& Surmiński J., 1970, Sosna zwyczajna Pinus sylvestris L., Zakład dendrologii i Arboretum Kórnickie Polskiej Akademii Nauk, Warszawa - Poznań.

Birdsey R.A. \& Lewis G.M., 2003, Carbon in U. S. Forests and Wood Products, 1987-1997: State-by-State Estimates, USDA Forest Service Delaware, USA.

Breymeyer A., 1998, Badania borów w transekcie klimatycznym wzdłuż równoleżnika $52^{\circ} \mathrm{N}$ (od $12^{\circ}$ do $\left.32^{\circ} \mathrm{E}\right)$ i na transekcie ,śląskim”. Założenia ogólne [Transect studies of pine forest along parallel $52^{\circ} \mathrm{N}, 12^{\circ}$ to $32^{\circ} \mathrm{E}$ and along pollution gradient in Central Europe: General Assumptions, climatic conditions and pollution deposition], (in:) A. Breymeyer, E. Roo-Zielińska (eds) Bory sosnowe w gradiencie kontynentalizmu i zanieczyszczeń w Europie Środkowej : badania geoekologiczne [Pine forests in Central European gradient of continentality and pollution], IG i PZ PAN, Dok. Geogr. 13: 11-29, Warszawa.

Breymeyer A., Mróż G., Reed D., Degróski M., 1998, Warunkowanie tempa dekompozycji ściółki sosnowej przez zmieniający się klimat i skład chemiczny substratu. Badania na transektach [The conditioning of rates of pine-litter decomposition by changing cli mate and substrate chemical composition. Transect studies], (in:) A. Breymeyer, E. Roo-Zielińska (eds.) Bory sosnowe $\mathrm{w}$ gradiencie kontynentalizmu i zanieczyszczeń w Europie Środkowej : badania geoekologiczne [Pine forests in Central European gradient of continentality and pollution], IG i PZ PAN, Dok. Geogr. 13: 187-205, Warszawa.

Burschel P., Kürsten E. \& Larson B.C., 1993, Die Rolle von Wald und Forstwirtschaft im Kohlenstohaushalt eine Betrachtung für die Bundesrepublik Deutschland, Forstl. Versuchs u. Forschungsanst, 126: 135.

Cannell M.G., 2003, Carbon sequestration and biomass energy o set: theoretical, potential and achievable ca- 
pacities globally, in Europe and the UK, Biomass and Bioenergy, 24: 97-116.

Czuraj M., 1990, Tablice miąższości kłód odziomkowych i drzew stojących [Volume tables basal logs and standing trees], Państwowe Wydawnictwo Rolnicze i Leśne, Warszawa.

Deptuła M., 2004, Wpływ zmiany sposobu użytkowania terenu na kumulację węgla w krajobrazie, praca doktorska wykonana w Pracowni Modelowania Procesów Ekologicznych, [The impact of land use change on the accumulation of carbon in the landscape, Doctoral Thesis performed at the Laboratory for Ecological Processes Modeling], Nicolaus Copernicus University, Torun

Deptuła M., 2006, Influence of the past economy on the stucture, carbon accumulation and species diversity od the forest stands and phytocenoses, Ecological Questions, 7: 57-58.

Dyrektor Generalny Lasów Państwowych [Managing Director of State Forest], 2003, Zasady hodowli lasu obowiązujące w Państwowym Gospodarstwie Leśnym Lasy Państwowe [Principles of silviculture in force in the State Forests National Forest Holding], Warszawa.

Dyrektor Generalny Lasów Państwowych [Managing Director of State Forest], 2012, Zasady hodowli lasu obowiązujące w Państwowym Gospodarstwie Leśnym Lasy Państwowe [Principles of silviculture in force in the State Forests National Forest Holding], Warszawa.

Finèr L., Mannerkoski H., Piirainen S. \& Starr M., 2003, Carbon and nitrogen in an old-growth, Norwy spruce mixed forest in eastern Finland and changes associated with clear-cutting, Forest Ecology and Management, 174: 51-63.

Fonseca W., Benayas J.M.R. \& Alice F.E., 2011, Carbon accumulation in the biomass and soil of different aged secondary forests in the humid tropics of Costa Rica, Forest Ecology and Management, 262: 1400-1408.

GIOŚ, 2012, 4030 Suche wrzosowiska (Calluno-Genistion, Pohlio- Callunion, Calluno-Arctostapylion), [in:] Monitoring gatunków i siedlisk przyrodniczych ze szczególnym uwzględnieniem specjalnych obszarów ochrony siedlisk Natura 2000 [Monitoring of species and habitats with special emphasis on special areas of conservation of Natura 2000], Warszawa.

Hansen P.J.K., 2009, What do the learner know about clouds, precipitation, wind and greenhouse effect; a short review of research from 1883 to 2009 , [in:] $9^{\text {th }}$ EMS Annual Meeting, 9th European Conference on Applications of Meteorology (ECAM), Sept. 28 - Oct. 2, 2009 in Toulouse, Abstracts, id. EMS2009-237(Vol. 1, p. 237), Toulouse, France.

IPCC, 2007, Contribution of Working Group I to the Fourth Assessment Report of the Intergovernmental Panel on Climate Change, S. Solomon, D. Qin, M. Manning,
Z. Chen, M. Marquis, K.B. Averyt, M. Tignor, H.L. Miller (eds), Cambridge, UK and New York, USA.

Karjalainen T., Pussinen A., Liski J., Nabburs G., Erhard M., Eggers T., Sonntag M. \& Mohren G.M., 2002, An approach towards an estimate of the impact of forest management and climate change on the Europan forest sector carbon budget: Germany as a case study, Forest Ecology and Management, 162: 87-103.

Karjalainen T., Pussinen A., Liski J., Nabburs G., Erhard M., Eggers T., Lapvetaläinen T. \& Kaipainen T., 2003, Scenario analysis of the impact of forest management and climate change on the European forest sector carbon budget, Forest Policy and Economics, 5: 141-155.

Keeling C.D., Bacastow R.B., Carter A.F., Piper S.C., Whorf T.P., Heimann M., Mook W.G. \& Roeloffzen H., 1989, A three-dimensional model of atmospheric $\mathrm{CO}_{2}$ transport based on observed winds. 1. Analysis of observed data, Geophys. Monogr., 55: 165-236.

Kinman J. D., Kaster G., Kuhn E. C., Smithson J. A. \& Brown G., 2000, Forest carbon management, the greenhouse effect and electric utilities, Environmental Science \& Policy, 3: 115-122.

Kruczyńska A., 2012, Struktura drzewostanu i zmiany florystyczne wydmy Zadroże, praca licencjacka wykonana w Pracowni Modelowania Procesów Ekologicznych, [Forest stand structure and floristic changes dunes Zadroże, bachelor performed at the Laboratory for Ecological Processes Modeling], Nicolaus Copernicus University, Toruń.

Krzysik F., 1978, Nauka o drewnie [Learning about wood], Państwowe Wydawnictwo Naukowe, Warszawa.

Kurbanov E.A. \& Post W.M., 2002, Changes in area and carbon in forests of the middle Zavolgie: A regional case study of Russian Forests, Climatic Change 55: $157-173$.

Laurow Z., 1966, Kompleksowe użytkowanie arbomasy leśnej [Comprehensive use of forest arbomasy], Wyd. Świat, Warszawa..

Liski J., Perruchoud D. \& Karjalainen T., 2002, Increasing carbon stocks in the forest soils of western Europe, Forest Ecology and Management, 169: 159-175.

Lauschner Ch. \& Rode M.W., 1999, The role of plant resources in forest succession: changes in radiation, water and nutrient fluxes, and plant productivity over a 300-yr-long chronosequence in NW-Germany, Perspectives in Plant Ecology, Evolution and Systematics, 2: 103-147.

Lieth H., 1975, Primary producitivity of the major vegetation units of the world, [in:] H. Lieth, R. H. Whittaker (eds), Primary producitivity of the biosphere, Ecol. Stud., 14: 203-231.

Łukaszkiewicz J., 2010, Określanie wieku niektórych gatunków drzew ulicznych na podstawie wybranych parametrów dendrometrycznych [Determination of the age 
of some species of trees street on the basis of selected parameters dendrometrycznych], Rocznik Polskiego Towarzystwa Dendrochronologicznego, 58: 25-38.

Miejska Pracownia Urbanistyczna w Toruniu [Municipal Urban Laboratory in Toruń], 2006, Studium uwarunkowań i kierunków zagospodarowania przestrzennego Miasta Torunia [Urban Planning of Toruń], Toruń.

Mund M., Kummetz E., Hein M., Bauer G.A. \& Schulze E.D., 2002, Growth and carbon stocks of a spruce forest chronosequence in central Europe, Forest Ecology and Management, 171: 275-296.

Murillo-Rodriquez J.C., 1994, The carbon budget of the Spanish forests, Biogeochemistry, 24: 1-21.

Murillo-Rodriquez J.C., 1997, Temporal variations in the carbon budget of forest ecosystems in Spain, Ecological Applications, 7: 461-469.

Nabuurs G.J., Schelhaas M.J., 2003, Spatial distribution of whole-tree carbon stock and fluxes across the forests of Europe: where are the options for bio-energy? Biomass and Bioenergy, 24: 311-320.

Nienartowicz A., Kunz M., Deptuła M. \& Domin D., 2002, Ecological consequences of changes in landscape structure in the neighbourhood of Brusy in 19th and 20th century, Ecological Questions, 1: 117-135.

Nienartowicz A., Kunz M., Adamska E., Boińska U., Deptuła M., Gugnacka-Fiedor W., Kamiński D. \& Rutkowski L., 2009, Relief and changes in the vegetation cover and the flora of the Zadroże une near the city Torun: Comparision of the condition in 1948 and 2009, Ecological Questions, 12, Special Issue: 17-49.

Okołowicz W., 1949, Opis geograficzny wydmy Zadroże [The geographical description of the dune Zadroże], [in:] J. Prüffer (ed.), Z badań zespołowych wydmy Zadroże [Collective investigations concerning the Zadroże dune near Toruń], Studia Societaris Scientiarum Torunensis, Supplementum, I: 3-10.

Orihuela - Belmonte D.E., de Jong B.H.J., Mendoza Vega J., Van der Wal J., Paz-Pellat F., Soto - Pinto L. \& Flamenco - Sandoval A., 2013, Carbon stocks and acumulation rates in tropical secondary forests at the scale of community, landscape and forest type, Agruculture, Ecosystems and Environment, 171: 72-84.

Patenaude G.L., Briggs B.D., Milne R. Rowland C.S., Dawson T.P., Pryor S.N., 2003, The carbon pool in a British semi-natural woodland, Forestry 75 (5): 109119.

Preece N.D., Crowley G.M., Lawes M.J. \& van Oosterzee P., 2012, Comparing above-ground biomass among forest types in the Wet Tropics: Small stems and plantation types matter in carbon accounting, Forest Ecology and Management, 100: 228-237.
Rode M.W., 1999a, Influence of forest growth on former heathland on nutrient input and its consequences for nutrition and management of heath and forest, Forest Ecology and Management, 114: 31-43.

Rode M.W., 1999b, The interaction between organic layer and forest growth and forest development on former heathland, Forest Ecology and Management, 114: 117-127.

Traczyk T., 1968, Studies on the primary production in meadow community, Ekologia Polska Ser. A, 16: 59100

Traczyk T., 1971, Productivity and investigation of two types of meadows in the Vistula valley. I Geobotanical description and primary production Ekologia Polska Ser. A, 19: 93-106.

Whittaker R.H., 1975, Communities and ecosystems, Second edition. Macmilan, New York.

Whittaker R.H. \& Marks P.L., 1975, Methods of assesings terrestrial productivity, [in:] H. Lieth, R.H. Whittaker (eds), Primary productivity of the biosphere, 3: 55-118. www.geoportal.gov.pl

von Oheimb G., Härdtle W., Naumann P. S., Westphal Ch., Assmann T.\& Meyer H., 2008, Long-term effects of historical heathland farming on soil properties of forest ecosystems, Forest Ecology and Management, 255: 1984-1993.

Vucetich J.A., Reed D.D., Breymeyer A., Degórski M., Mroz G.D., Solon J., Roo-Zielinska E. \& Noble R., 2000, Carbon pools and ecosystem properties along a latitudinal gradient in northern Scots pine (Pinus sylvestris) forests, Forest Ecology and Management, 136: 135-145.

Zhang H., Guan D. \& Song M., 2012, Biomass and carbon storage of Eucalyptus and Accacia plantations in the Pearl River Delta, South China, 277: 90-97.

Zhang X.Q. \& Xu D., 2003, Potential carbon sequestration in China's forests, Environmental Science \& Policy, 6: 421-432.

Zhong L., Werner A., Kurz M.J., Apps J. \& Beukema S., 2003, Belowground biomass dynamics in the Carbon Budget Model of the Canadian Forest Sector: recent improvements and implications for the estimation of NPP and NEP. Can J. For. Res. 33: 126-136. 